\title{
Hirsutism Induced by Facial Autologous Fat Grafting
}

\author{
Yuval Ramot $^{\mathrm{a}}$ Tatiana Silyuk $^{\mathrm{b}}$ Sari Murad ${ }^{\mathrm{a}}$ Abraham Zlotogorski $^{\mathrm{a}}$ \\ a Department of Dermatology, Hadassah Medical Center, Hebrew University of Jerusalem, The Faculty of Medicine, \\ Jerusalem, Israel; ${ }^{\mathrm{b}}$ The Hair Treatment and Transplantation Center, Saint Petersburg, Russia
}

\section{Established Facts}

- Autologous fat grafting (AFG) is an established technique used for aesthetic purposes, including facial rejuvenation.

- The procedure is considered safe, with only mild and uncommon side effects.

\section{Novel Insights}

- We report on a patient who developed hirsutism 1 month following facial AFG.

- This is the first report on hirsutism following AFG, which might be mediated by the secretion of growth factors from the graft.

\section{Keywords}

Autologous fat injection · Hirsutism · Hair

\begin{abstract}
Autologous fat grafting (AFG) is a common procedure, which gains popularity for a large number of indications, mainly for reshaping and filling of contour defects. It is considered a safe procedure, with only uncommon and mild complications. Here we report on a 60-year-old female patient who developed excess hair growth on both cheeks 1 month following facial AFG done in conjunction with a facelift. Complete endocrine evaluation was within normal levels. Previous reports have suggested that adipocyte mesenchymal
\end{abstract}

\section{KARGER}

(c) 2019 S. Karger AG, Basel

E-Mail karger@karger.com

www.karger.com/sad stem cells can secrete a number of growth factors, which in turn can lead to activation of stem cells in the hair follicle, affecting their growth. However, to the best of our knowledge, this is the first report on hirsutism as a side effect of AFG.

(c) 2019 S. Karger AG, Basel

\section{Introduction}

Autologous fat grafting (AFG) is a technique used for reshaping and filling of contour defects [1]. Its use has been gaining popularity in the last 30 years, and it is currently being used for a large number of indications, including hand, facial, and breast rejuvenation, correction 
Fig. 1. Excess hair growth on the cheeks of the patient, as observed 4 months following autologous fat grafting.
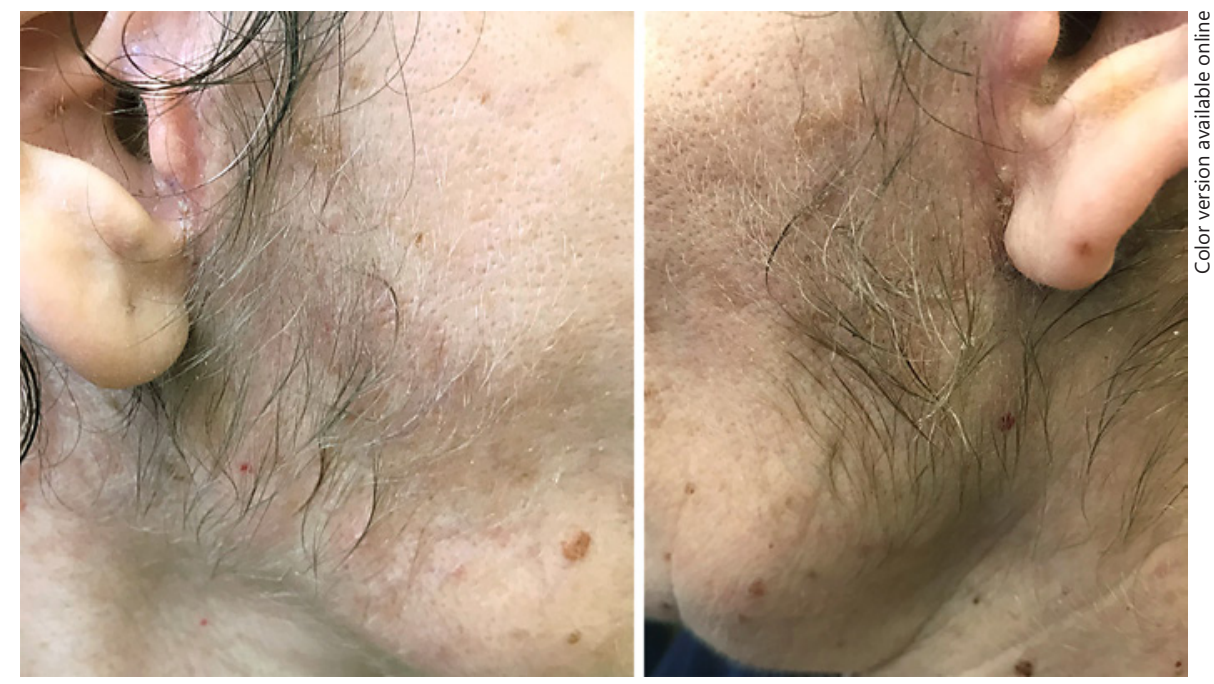

of photoaging, treatment of atrophy of the plantar fat pad, improvement of hyperpigmentation, and scar tissue softening [2]. AFG is considered a safe procedure utilizing autologous material and not foreign material, with minimal scarring at the injection site and a low incidence of side effects [2]. Nevertheless, complications have been observed with this technique, with a complication rate of approximately $6 \%$ when AFG is used for facial rejuvenation. Complications are mostly mild in severity and can include hematoma/ecchymosis, fat necrosis/oil cysts, scars, swelling, and irregular distribution of fat. Infections are reported more rarely [3], and fat necrosis and blindness and stroke have been reported but are extremely rare. Here we report on a patient that developed diffuse hirsutism in the vicinity of the fat injections, a complication that, to the best of our knowledge, has not been reported before.

\section{Case Report}

A 60-year-old female presented to the department of dermatology 4 months following a facelift surgery that was accompanied by an AFG to both cheeks. The surgery and the fat injection went without any apparent side effects, and post-surgery follow-up was normal. One month following the procedure, the patient noticed excess hair growth on both cheeks, in the vicinity of the fat injections. The patient denied excess hair growth in any other location or any related symptoms. A complete endocrine panel did not reveal any sex hormone abnormalities. The patient was in general good health, except for osteoporosis, treated periodically with denosumab. Examination revealed slight hyperpigmentation disseminated symmetrically on both cheeks, covered by a combination of vellus and black and white terminal hairs (Fig. 1).

\section{Discussion}

Although most of the literature on fat grafting discusses its potential use on skin rejuvenation and as a filling material, it has been reported that fat injection can also affect the hair follicle. Most of these effects have been attributed to the presence of adipocyte mesenchymal stem cells, which can lead to activation of the stem cells in the hair follicle, resulting in regeneration of the hair follicle [4]. This is presumably achieved by the secretion of growth factors that can lead to paracrine effects on cells in their vicinity [5]. Indeed, conditioned medium of adipose tissue-derived stem cells have been shown to promote hair growth in vitro $[6,7]$. Based on these in vitro studies, conditioned medium of adipose tissue-derived stem cells has been used for the treatment of female pattern hair loss, with favorable results [8]. Enriched adipose tissue has also been found to be effective in a series of patients with male pattern baldness and female pattern hair loss [9]. There are also reports on the use of fat grafting for inducing hair regrowth in a patient with atrophic scarring alopecia and in a patient with scleroderma-induced atrophic alopecia $[10,11]$.

To our knowledge, although there is a theoretical basis for hair growth-promoting effects of AFG, this is the first report on hirsutism as a complication of AFG when used for facial rejuvenation. This may be the result of underreporting of this complication, and increased awareness by treating physicians for this possibly rare side effect is needed. Further studies on the possible effects of AFG on hair growth and the hair follicle stem cells will help decipher the exact mechanism that underlies these effects. 


\section{Statement of Ethics}

Written consent was obtained from the patient.

\section{Disclosure Statement}

The authors have no conflicts of interest to disclose.

\section{References}

1 Ruan QZ, Rinkinen JR, Doval AF, Scott BB, Tobias AM, Lin SJ, et al. Safety profiles of fat processing techniques in autologous fat transfer for breast reconstruction. Plast Reconstr Surg. 2019 Apr;143(4):985-91.

2 Landau MJ, Birnbaum ZE, Kurtz LG, Aronowitz JA. Review: proposed methods to improve the survival of adipose tissue in autologous fat grafting. Plast Reconstr Surg Glob Open. 2018 Aug;6(8):e1870.

3 Groen JW, Krastev TK, Hommes J, Wilschut JA, Ritt MJ, van der Hulst RR. Autologous fat transfer for facial rejuvenation: A systematic review on technique, efficacy, and satisfaction. Plast Reconstr Surg Glob Open. 2017 Dec;5(12):e1606

4 Festa E, Fretz J, Berry R, Schmidt B, Rodeheffer M, Horowitz M, et al. Adipocyte lineage cells contribute to the skin stem cell niche to drive hair cycling. Cell. 2011 Sep;146(5):761-71.
5 Kinnaird T, Stabile E, Burnett MS, Lee CW, Barr S, Fuchs S, et al. Marrow-derived stromal cells express genes encoding a broad spectrum of arteriogenic cytokines and promote in vitro and in vivo arteriogenesis through paracrine mechanisms. Circ Res. 2004 Mar; 94(5):678-85.

6 Park BS, Kim WS, Choi JS, Kim HK, Won JH, Ohkubo F, et al. Hair growth stimulated by conditioned medium of adipose-derived stem cells is enhanced by hypoxia: evidence of increased growth factor secretion. Biomed Res. 2010 Feb;31(1):27-34.

7 Won CH, Yoo HG, Park KY, Shin SH, Park WS, Park PJ, et al. Hair growth-promoting effects of adiponectin in vitro. J Invest Dermatol. 2012 Dec;132(12):2849-51.
8 Shin $\mathrm{H}$, Ryu HH, Kwon O, Park BS, Jo SJ. Clinical use of conditioned media of adipose tissue-derived stem cells in female pattern hair loss: a retrospective case series study. Int J Dermatol. 2015 Jun;54(6):730-5.

9 Perez-Meza D, Ziering C, Sforza M, Krishnan G, Ball E, Daniels E. Hair follicle growth by stromal vascular fraction-enhanced adipose transplantation in baldness. Stem Cells Cloning. $2017 \mathrm{Jul} ; 10: 1-10$.

10 Cho SB, Roh MR, Chung KY. Recovery of scleroderma-induced atrophic alopecia by autologous fat transplantation. Dermatol Surg. 2010 Dec;36(12):2061-3.

11 Dini M, Mori A, Quattrini Li A. Eyebrow regrowth in patient with atrophic scarring alopecia treated with an autologous fat graft. Dermatol Surg. 2014 Aug;40(8):926-8. 